\title{
Assay and physicochemical characterization of the antiparasitic albendazole
}

\author{
Noely Camila Tavares Cavalcanti ${ }^{*}$, Giovana Damasceno Sousa ${ }^{2}$, Maria Alice Maciel Tabosa ${ }^{1}$, José $^{2}$ \\ Lamartine Soares Sobrinho ${ }^{3}$, Leila Bastos Leal ${ }^{1}$, Davi Pereira de Santana ${ }^{1}$
}

\author{
${ }^{1}$ Pharmaceutical and Cosmetics Development Center, NUDFAC, Federal University of Pernambuco, ${ }^{2}$ Pernambuco's Health \\ College, FPS, Recife, ${ }^{3}$ Center of Pharmaceutical Technology, Federal University of Piaui
}

\begin{abstract}
The aim of this study was to characterize three batches of albendazole by pharmacopeial and complementary analytical techniques in order to establish more detailed specifications for the development of pharmaceutical forms. The ABZ01, ABZ02, and ABZ03 batches had melting points of $208^{\circ} \mathrm{C}, 208^{\circ} \mathrm{C}$, and $209^{\circ} \mathrm{C}$, respectively. X-ray diffraction revealed that all three batches showed crystalline behavior and the absence of polymorphism. Scanning electron microscopy showed that all the samples were crystals of different sizes with a strong tendency to aggregate. The samples were insoluble in water $(5.07,4.27$, and $4.52 \mathrm{mg} \mathrm{mL}^{-1}$, respectively) and very slightly soluble in $0.1 \mathrm{M} \mathrm{HCl}\left(55.10,56.90\right.$, and $61.70 \mathrm{mg} \mathrm{mL}^{-1}$, respectively) and additionally showed purities within the range specified by the Brazilian Pharmacopoeia 5th edition (F. Bras. V; 98\% to 102\%). The pharmacopeial assay method was not reproducible and some changes were necessary. The method was validated and showed to be selective, specific, linear, robust, precise, and accurate. From this characterization, we concluded that pharmacopeial techniques alone are not able to detect subtle differences in active pharmaceutical ingredients; therefore, the use of other complementary techniques is required to ensure strict quality control in the pharmaceutical industry.
\end{abstract}

Uniterms: Albendazole/characterization. Antiparasitics/quality control.

\begin{abstract}
O objetivo do trabalho foi caracterizar três lotes de albendazol com técnicas analíticas farmacopéicas e complementares a fim de estabelecer especificações mais detalhadas para o desenvolvimento de formas farmacêuticas. Os lotes ABZ01, ABZ02 e ABZ03 apresentaram fusão em $208{ }^{\circ} \mathrm{C}, 208{ }^{\circ} \mathrm{C}$ e $209{ }^{\circ} \mathrm{C}$. Foi possível evidenciar, por difração de raios $\mathrm{X}$, que os três lotes apresentaram comportamento cristalino e ausência de polimorfismo. Através da microscopia eletrônica de varredura verificou-se que todas as amostras apresentaram cristais com diferentes tamanhos e forte tendência de agregação. As amostras foram insolúveis em água $\left(5,07 ; 4,27\right.$ e 4,52 $\left.\mu \mathrm{g} \mathrm{mL}^{-1}\right)$ e muito pouco solúveis em $\mathrm{HCl} 0,1 \mathrm{M}(55,10$; 56,90 e $\left.61,70 \mu \mathrm{g} \mathrm{mL}^{-1}\right)$ e, ainda, apresentaram pureza dentro da faixa especificada pela F.Bras.V ( $98 \%$ a $102 \%)$. O método farmacopéico de doseamento não foi reprodutível, e algumas mudanças foram necessárias. O método foi validado e demonstrou ser seletivo, específico, linear, robusto, preciso e exato. A partir dessa caracterização, pode-se concluir que apenas técnicas farmacopéicas não são capazes de detectar diferenças sutis entre os ingredientes farmacêuticos ativos, necessitando, portanto, de uso de outras técnicas complementares para garantir um rígido controle de qualidade na indústria farmacêutica.
\end{abstract}

Unitermos: Albendazol/caracterização. Antiparasitários/controle de qualidade.

\section{INTRODUCTION}

Characterization of the physical and physicochemical properties of drugs is essential for the develop-

*Correspondence: N.C.T. Cavalcanti. Núcleo de Desenvolvimento Farmacêutico e Cosmético - NUDFAC, Universidade Federal de Pernambuco - UFPE. Av. Professor Artur de Sá, s/n, Cidade Universitária, 50740-521 - Recife - PE, Brazil. E-mail: noely.cavalcanti@nudfac.com.br ment of pharmaceutical forms and is the first step in the drug design process. Changes in the active pharmaceutical ingredient (API) may impair productivity, affect product quality, and even cause the loss of a production batch (Nery et al., 2008; Soares Sobrinho et al., 2010).

Albendazole (ABZ; methyl-5-propylthio-2-benzimidazolecarbamate; Figure 1), a member of the benzimidazole family of compounds, is a crystalline white 
odorless powder that melts at $207{ }^{\circ} \mathrm{C}-209^{\circ} \mathrm{C}$. It has a molecular weight of $265.34 \mathrm{~g} \mathrm{~mol}^{-1}$ and the molecular formula is $\mathrm{C}_{12} \mathrm{H}_{15} \mathrm{~N}_{3} \mathrm{O}_{2} \mathrm{~S}$. In the Biopharmaceutical Classification System (BCS), it is a Class II substance, with low solubility and high permeability (Merck Index, 1996; Lindenberg et al., 2004).<smiles>CCCSc1ccc2[nH]c(NC(=O)OC)nc2c1</smiles>

FIGURE 1 - Chemical structure of albendazole.

The molecule was patented in 1975 but there were no reports available regarding its solid-state characterization or possible polymorphisms. In 2010, Pranzo et al. showed that the re-crystallization of ABZ from methanol and $N, N$-dimethylformamide affords a new stable polymorphic form (Form II), enantiotropically related to the commercially available ABZ.

ABZ is the API most widely used for controlling intestinal parasites, because it has broad-spectrum activity, is well tolerated, and has low cost (Moriwaki et al., 2008). According to the National Health Surveillance Agency (ANVISA), the reference drug is Zentel ${ }^{\circledR}$ (GlaxoSmithKline), and currently, there are 11 types of generic medications from several pharmaceutical laboratories in Brazil. ABZ is available in the form of $200 \mathrm{mg}$ tablets, $400 \mathrm{mg}$ chewable tablets, and a $400 \mathrm{mg} 10 \mathrm{~mL}^{-1}$ oral suspension (ANVISA, 2010).

Knowing that $\mathrm{ABZ}$ is a class II (BCS) substance and considering that the presence of polymorphic forms could cause changes in the melting point, density, solubility, dissolution, physical or chemical stability, and consequently drug bioavailability, it is extremely important to obtain in-depth knowledge of the drug, if the required pharmacopeial tests are not enough to identify subtle differences among the raw materials, especially in pre-formulation studies, thereby threatening the quality of the product. Thus, it is very important to use different parameters, e.g., melting point, and techniques, e.g., infrared spectroscopy and X-ray diffraction, for characterization (Nery et al., 2008; Storpirtis et al., 2009; Maximiano, 2010).

Therefore, the aim of this study was to evaluate the physical and physicochemical characteristics of ABZ through different identification and characterization tests, as a way to establish quality standards and aid technological improvements in this antiparasitic drug.

\section{MATERIAL AND METHODS}

ABZ was provided by Formil Química ${ }^{\circledR}$ (Barueri,
Brazil), batches 1005024006,1005022006 , and 1002008006, which for the proposed study were identified as ABZ01, ABZ02, and ABZ03, respectively. Pharmacopeial Standard Batch 1034, content $(99.80 \%)$ INCQS, Rio de Janeiro, Brazil. All solvents and reagents used in the trials were of analytical grade, the glassware was calibrated, and the tests described below were performed in 3 replicates.

To improve understanding, the analyses were classified as pharmacopeial and non-pharmacopeial (complementary), owing to some discriminative characteristic methods cited in the Brazilian Pharmacopoeia 5th edition (F. Bras. V, 2010).

\section{PHARMACOPEIAL TESTS}

\section{Organoleptic characterization}

Organoleptic characteristics were compared to those described in the F. Bras. V (2010) and Drug Master File (DMF) for the API provided by Formil Química ${ }^{\circledR}$.

\section{Infrared spectroscopy}

Infrared spectroscopy with a $\mathrm{KBr}$ tablet was verified using a Fourier Transformed Infrared Spectrometer (model IFS66, Bruker, Madison, WI, USA). The spectrum of the API was drawn in the range of $4000 \mathrm{~cm}^{-1}$ to $400 \mathrm{~cm}^{-1} \mathrm{ac}-$ cording to the method described in the F. Bras. V (2010).

\section{Melting point}

The melting point was evaluated using a Mars' Fusiometer, model III, in accordance with the general method of F. Bras. V (2010) and by differential thermal analysis (DTA).

\section{Assay}

Initially, $40 \mathrm{mg}$ of ABZ was weighed into a $50 \mathrm{~mL}$ round-bottomed volumetric flask; $37 \% \mathrm{HCl}$ was added to $10 \%$ of the flask volume; and then the volume was made up with methanol from a stock solution (concentration, $800 \mu \mathrm{g} \mathrm{mL}^{-1}$ ). The solution was shaken with a magnetic bar for 5 min and subjected to dispersion in an ultrasonic bath for a further $5 \mathrm{~min}$. To evaluate the content, an analytical curve was used, in triplicate, with concentrations of 60,80 , $120,180,320 \mu \mathrm{g} \mathrm{mL}^{-1}$, generated by dilution of the stock solution in monobasic sodium phosphate/methanol (40:60) buffer and analyzed by high-performance liquid chromatography coupled with an ultraviolet detector (HPLC-UV) 
set at $308 \mathrm{~nm}$. The concentration of $120 \mu \mathrm{g} \mathrm{mL} \mathrm{L}^{-1}$ was considered $100 \%$.

The chromatographic conditions were as follows: stationary phase: Luna $5 \mu \mathrm{m} \mathrm{C} 18$ column, $100 \AA$, $250 \times 4.6 \mathrm{~mm}$; mobile phase: monobasic sodium phosphate/methanol buffer (40:60), $\mathrm{pH} 4.8$, isocratic; flow rate: $2.0 \mathrm{~mL} \mathrm{~min}^{-1}$; detector: UV (308 nm), Temperature: $40^{\circ} \mathrm{C}$, and injection volume: $20 \mathrm{~mL}$.

The validation process was performed according to the present guidelines contained in Resolution RE-899 passed on May 29, 2003 (ANVISA, 2003). To evaluate selectivity and specificity, 3 standard and placebo batches were used at the working concentration $\left(120 \mu \mathrm{g} \mathrm{mL}^{-1}=\right.$ $100 \%$ theoretical concentration). Linearity was obtained from a standard calibration curve, in triplicate, with 5 standard solutions at concentrations corresponding to 60 , $80,120,160$, and $320 \mu \mathrm{g} \mathrm{mL}^{-1}$, expressed by the correlation coefficient obtained through the least squares method.

Precision was evaluated based on repeatability, i.e., correlation between results obtained within a short period of time using the same instrumentation and analyst. Six analytical solutions of the sample were used at the working concentration $\left(120 \mu \mathrm{g} \mathrm{mL}^{-1}=100 \%\right.$ theoretical concentration) and for intermediate precision methods, batches in triplicate at the same working concentration were used, on different days by different analysts.

For accuracy, we used samples in triplicate, at concentrations equivalent to 60,120 , and $180 \mu \mathrm{g} \mathrm{mL}^{-1}$, corresponding to $50 \%, 100 \%$, and $150 \%$ of the theoretical concentration of the tested drug, ABZ. Robustness was evaluated by varying parameters such as the manufacturer of methanol and shaking time (5 and $10 \mathrm{~min})$. The results were analyzed using analysis of variance (ANOVA), relative standard deviation, or coefficient of variation and Student $t$-test.

\section{Solubility}

Solubility studies were performed using a large quantity of drug in $25 \mathrm{~mL}$ of 2 liquids (water and $0.1 \mathrm{M} \mathrm{HCl}$ ). $\mathrm{ABZ}$ samples were initially submitted to ultrasound dispersion for $5 \mathrm{~min}$ and placed under magnetic stirring at $25^{\circ} \mathrm{C}$ $\left( \pm 2{ }^{\circ} \mathrm{C}\right)$ for $24 \mathrm{~h}$. They were then submitted to centrifugation at $3000 \mathrm{rpm}$ for $30 \mathrm{~min}$, and a $100 \mu \mathrm{L}$ sample was taken from the supernatant, diluted to $10 \mathrm{~mL}$, filtered $(0.22 \mu \mathrm{m})$, and measured by HPLC-UV with detection at $308 \mathrm{~nm}$.

\section{COMPLEMENTARY TESTS}

\section{Nuclear Magnetic Resonance Spectroscopy}

In order to complement the identification of raw materials, nuclear magnetic resonance (NMR) analyses were performed. Proton $\left({ }^{1} \mathrm{H}\right)$ and Carbon-13 $\left({ }^{13} \mathrm{C}\right)$ NMR experiments were performed on a Varian ${ }^{\circledR}$ spectrometer, model Unity plus-300 MHz (Palo Alto, CA), using dimethyl sulfoxide as the solvent.

\section{Flow properties}

Density was determined by testing $20 \mathrm{~g}$ of each sample using an automatic compactor (Tapped Density Tester Varian 50-100) equipped with a calibrated cylinder. The initial volume of the sample was verified and 10 compressions were performed for powder accommodation. Then, 1250 compressions were done. The relationship between the mass $(\mathrm{g})$ and the volume $(\mathrm{mL})$ occupied by the powder before and after compression determined the apparent density (ApD) and the compression density $(\mathrm{CpD})$, respectively. The Hausner index (HI) and the Carr index $(\mathrm{CI})$ were calculated using the following equations: $\mathrm{HI}=\mathrm{ApD} / \mathrm{CpD}$ and $\mathrm{CI}=(\mathrm{CpD}-\mathrm{ApD}) / \mathrm{CpD} \times 100(\mathrm{USP}$, 2007; Soares Sobrinho et al., 2008; Alves et al., 2008).

The angle of repose was measured using a protractor from the conical pile of powder formed by the flow of the API through a funnel of standardized dimensions on a flat surface. Flow time was determined by measuring the time required to drain $30 \mathrm{~g}$ of the API through a standardized funnel, using a digital stopwatch (Carini et al., 2009).

\section{X-ray diffraction}

X-ray diffraction analysis (XRD) was performed using a model D5000 diffractometer (Siemens, Munich, Germany) with an operating current of $40 \mathrm{~mA}$, under a $40 \mathrm{kV}$ tension, traversing the region between $2^{\circ}$ and $40^{\circ}$ (20) (Alanazi et al., 2007; Lopes, 2007).

\section{Granulometric and crystal morphology analysis}

Morphological analysis of ABZ particles was carried out by scanning electron microscopy (SEM), with a SS-550 microscope (Shimadzu, Kyoto, Japan), a working distance (WD) of $13 \mathrm{~mm}$, and 800-, 4500- and 15000-fold magnification. Samples were previously metalized with a 25-nm thick layer of gold for a duration of $2.5 \mathrm{~min}$ (Quick Coater's Sputter, model SC701, Sanyu Electron, Tokyo, Japan).

Particle size distribution was determined by sieving $30 \mathrm{~g}$ of the material through standardized and superimposed Bertel ${ }^{\circledR}$ sieves $(20,40,60,80$, and 100 mesh) for $20 \mathrm{~min}$ (Medeiros, 2010). Another technique applied was particle size distribution by laser diffraction and photon 
correlation spectroscopy (PCS), in a Delsa ${ }^{\mathrm{TM}}$ Nano-S Particle Analyzer (Beckman Coulter, Brea, CA) at $25^{\circ} \mathrm{C}$ with a detection angle of $90^{\circ}$. A dispersion of $12 \mathrm{mg}$ of $\mathrm{ABZ}$ in $20 \mathrm{~mL}$ of a $0.02 \%(\mathrm{v} / \mathrm{v})$ aqueous solution of the surfactant Tween 80 was kept in an ultrasonic bath $(40 \mathrm{KHz})$ for 1 min. Due to the hydrophobicity, a tensoactive agent was used to facilitate particle dispersion. The results are reported in terms of average size \pm standard deviation.

\section{Thermal characterization}

Thermogravimetric analysis (TG) and DTA were performed for all 3 batches of ABZ.

TG and DTA were conducted using a thermal balance, model TGA Q60 (Shimadzu) in an atmosphere with a nitrogen flow of $50 \mathrm{~mL} \mathrm{~min}{ }^{-1}$. The sample weight was around $3 \mathrm{mg}( \pm 0.3)$, placed in a platinum crucible at a temperature range of $30{ }^{\circ} \mathrm{C}$ to $600{ }^{\circ} \mathrm{C}$ and a heating rate of $10{ }^{\circ} \mathrm{C} \mathrm{min}{ }^{-1}$. Prior to the tests, the instrument was calibrated using a sample of aluminum and zinc (Aulton, 2005; Alencar et al., 2006).

\section{RESULTS AND DISCUSSION}

\section{Pharmacopeial Tests}

\section{Organoleptic characterization}

All three batches ABZ01, ABZ02, and ABZ03 were white crystalline to pale yellowish powders with a characteristic odor, consistent with the characteristics described in the F. Bras. V (2010) and DMF.

\section{Infrared spectroscopy}

The infrared spectra of ABZ01, ABZ02, and ABZ03 were similar, with the presence of absorption bands at $3390.32 \mathrm{~cm}^{-1}$, representing the amide $\mathrm{NH}$ bond, and at $1711.71 \mathrm{~cm}^{-1}$, representing the ester $\mathrm{C}=\mathrm{O}$ bond, corresponding to the carbamate portion of the $\mathrm{ABZ}$ molecule. Another absorption band appears at $1622.06 \mathrm{~cm}^{-1}$, representing the aromatic $\mathrm{C}=\mathrm{C}$ bond, corresponding, along with the amide $\mathrm{NH}$ bond, to the benzimidazole portion of the ABZ molecule. Additionally, the absorption bands from the aliphatic hydrocarbon group at $2959.32 \mathrm{~cm}^{-1}$, the ether bond at $1096.12 \mathrm{~cm}^{-1}$, the $\mathrm{C}-\mathrm{H}$ bond at $1622.06 \mathrm{~cm}^{-1}$, and the $\mathrm{S}=\mathrm{C}$ bond at $1096.12 \mathrm{~cm}^{-1}$ confirm the authenticity of the API. The infrared spectrum from ABZ01 is represented in Figure 2.

\section{Melting point}

The measured melting points of the 3 batches, $\mathrm{ABZ} 01, \mathrm{ABZ} 02$, and $\mathrm{ABZ} 03$, were $208^{\circ} \mathrm{C}, 208^{\circ} \mathrm{C}$, and

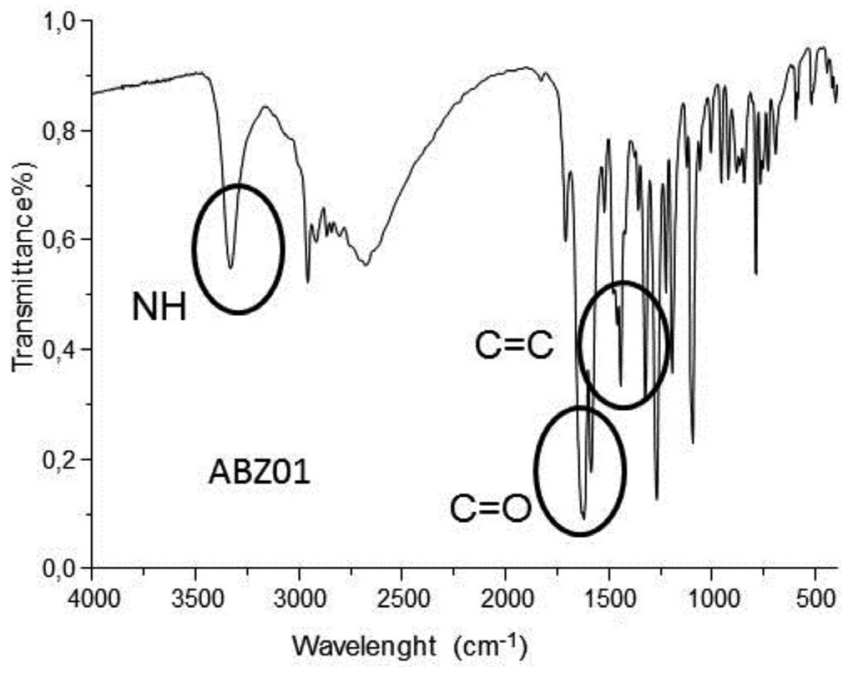

FIGURE 2 - Infrared spectrum of ABZ01 and its absorption bands.

$209{ }^{\circ} \mathrm{C}$, respectively, and based on DTA analysis, these values were $209.27^{\circ} \mathrm{C}, 209.89^{\circ} \mathrm{C}$, and $209.60^{\circ} \mathrm{C}$, respectively; both techniques yielded results in accordance with the F. Bras. V (2010) and DMF (Table I).

Assay

The pharmacopeial method was not reproducible because it presented differing results with variations above $5.0 \%$ for each batch; therefore, it was necessary to make changes in the method to achieve better results. These changes resulted in a good method with reproducible results, in accordance with the F. Bras. V (98\% to 102\%) (Table I).

TABLE I - Pharmacopeial test results

\begin{tabular}{lccc}
\hline \multirow{2}{*}{ Batches } & \multicolumn{2}{c}{ Melting Point $\left({ }^{\circ} \mathrm{C}\right)$} & \\
\cline { 2 - 3 } & $\begin{array}{c}\text { Method F. } \\
\text { Bras. V }\end{array}$ & DTA & Assay \\
\hline ABZ01 & 208 & 209.27 & $99.74 \% \pm 0.21 \%$ \\
ABZ02 & 208 & 209.89 & $100.01 \% \pm 0.12 \%$ \\
ABZ03 & 209 & 209.60 & $99.89 \% \pm 0.59 \%$ \\
\hline
\end{tabular}

The validated method showed selectivity and specificity, and there was no significant interference from other components (placebo) when compared with the standard samples. The calibration curve of ABZ was linear $(\mathrm{y}=$ $593976 x+2 E+06)$ with a correlation coefficient $\left(R^{2}\right)$ of 0.99, the minimum acceptable criterion (Figure 3).

The method showed repeatability in all 6 standard batches, with a relative standard deviation (RSD) of $1.44 \%$, within the $5 \%$ permitted by RE $899 / 2003$. The method also demonstrated intermediate precision when 


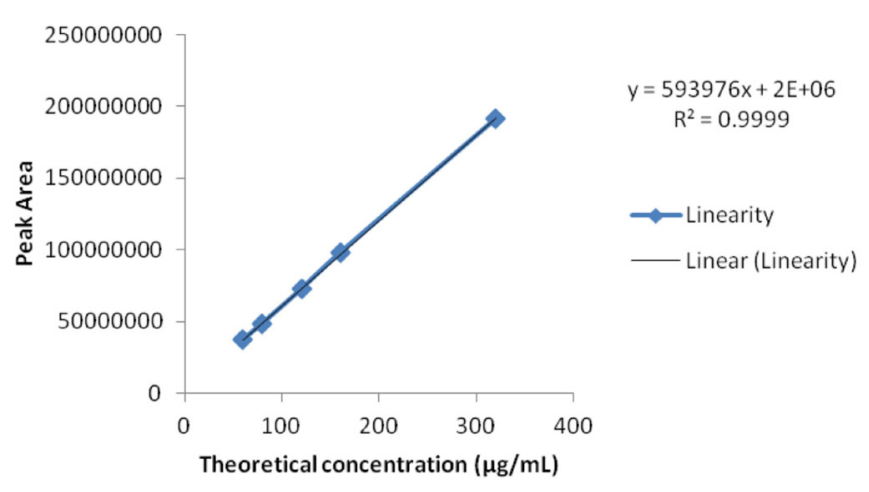

FIGURE 3 - Calibration curve of ABZ.

tested on different days by different analysts; there were no statistically significant differences between results obtained by different analysts and on different days, using the Student $t$-test. The calculated $t$ was $1.25,0.37,0.05$, and 1.01 between analysts on day 1 , between analysts on day 2 , between days for analyst 1 , and between days for analyst 2 , respectively, with all values lower than the critical $t$ (2.13), with $95 \%$ confidence.

The results for accuracy were close to $100 \%$, with coefficients of variation (CVs) of $0.13 \%, 0.013 \%$, and $0.07 \%$ for the theoretical concentrations of $50 \%, 100 \%$, and $150 \%$, respectively, according to Table II.

In the robustness test (Table III), when the manufacturer of methanol was changed, the calculated $t$ value (2.03) was lower than the critical $t$ value (2.91); similarly, when varying the shaking time ( 5 and $10 \mathrm{~min}$ ), the calculated $t$ value (1.92) was lower than the critical $t$ value (2.91). Thus, there were no statistically significant differences (Student $t$-test) with $95 \%$ confidence and this method can therefore be considered robust.

Therefore, this validated method was demonstrated to be selective, specific, linear, robust, precise, and accurate, providing the reliability required for an analytical method to be eligible for application in routine quality control laboratories.

\section{Solubility}

The 3 batches ABZ01, ABZ02, and ABZ03 showed aqueous solubilities of $5.07,4.27$, and $4.52 \mu \mathrm{g} / \mathrm{mL}$ (classified as insoluble), and in $0.1 \mathrm{M} \mathrm{HCl}$ solution presented solubilities of $55.10,56.90$, and $6170 \mu \mathrm{g} / \mathrm{mL}$, respectively (classified as very slightly soluble), according to F. Bras. V (2010).

\section{Complementary Tests}

\section{Nuclear Magnetic Resonance Spectroscopy}

${ }^{1} \mathrm{H}$ NMR data revealed a triplet at 0.95 and 2.85 ppm and a multiplet at 1.54 , corresponding to protons of alkyl groups. Further, the presence of a doublet at 7.33 and $7.11 \mathrm{ppm}$ and a singlet at $7.44 \mathrm{ppm}$ (corresponding to aromatic protons) as well as that of a doublet at $3.76 \mathrm{ppm}$ (corresponding to the $3 \mathrm{H}$ of a carbamate group) and at $11.67 \mathrm{ppm}$ (corresponding to a proton of the amino group) was also confirmed. The NMR ${ }^{13} \mathrm{C}$ chemical shifts indicate the presence of aliphatic carbons in the chemical shifts at $39.50,21.98$, and $12.88 \mathrm{ppm}$, aromatic carbons at 135.29, $114.00,123.97,126.87,115.73$, and $136.65 \mathrm{ppm}$, and carbonyl at $154.69 \mathrm{ppm}$. The chemical structure of ABZ is therefore confirmed through peaks, absorption, and the characteristic fragmentation of the molecule.

TABLE II - Results for accuracy in 3 concentrations $\left(60,120\right.$, and $\left.180 \mu \mathrm{g} \mathrm{mL}^{-1}\right)$ in triplicate, corresponding to $50 \%, 100 \%$, and $150 \%$ according to RE $899 / 03$

\begin{tabular}{ccccccc}
\hline Determinations & $60 \mu \mathrm{g} \mathrm{mL}-1$ & $\%$ & $120 \mu \mathrm{g} \mathrm{mL}^{-1}$ & $\%$ & $180 \mu \mathrm{g} \mathrm{mL}-1$ & $\%$ \\
\hline 1 & 60.49 & 100.82 & 119.52 & 99.60 & 179.71 & 99.84 \\
2 & 60.65 & 101.08 & 119.50 & 99.58 & 179.56 & 99.75 \\
3 & 60.61 & 101.02 & 119.48 & 99.57 & 179.81 & 99.89 \\
\hline
\end{tabular}

TABLE III - Results of robustness for the parameters evaluated: manufacturer of methanol and shaking time

\begin{tabular}{lccccc}
\hline \multirow{2}{*}{ Parameters } & \multicolumn{3}{c}{ Concentrations $\left(\mu \mathrm{g} \mathrm{mL}^{-1}\right)$} & \multirow{2}{*}{ Mean } & \multirow{2}{*}{ RSD \% } \\
\cline { 2 - 4 } & Sample 1 & Sample 2 & Sample 3 & & \\
\hline Methanol A & 120.77 & 121.77 & 120.26 & 120.93 & 0.63 \\
Methanol B & 120.26 & 120.09 & 119.91 & 120.08 & 0.14 \\
Shaking time 5 min & 120.88 & 120.24 & 119.89 & 120.30 & 0.41 \\
Shaking time 10 min & 121.86 & 120.82 & 120.93 & 120.97 & 0.46 \\
\hline
\end{tabular}




\section{Flow properties}

The bulk densities of ABZ01, ABZ02, and ABZ03 were $0.257 \mathrm{~g} \mathrm{~mL}^{-1}, 0.264 \mathrm{~g} \mathrm{~mL}^{-1}$, and $0.256 \mathrm{~g} \mathrm{~mL}^{-1}$, respectively; and the compressed densities were 0.408 $\mathrm{g} \mathrm{mL}^{-1}, 0.420 \mathrm{~g} \mathrm{~mL}^{-1}$, and $0.400 \mathrm{~g} \mathrm{~mL}^{-1}$, respectively. The $\mathrm{CI}$ indicates the powder compression capacity; for values between $5 \%$ and $15 \%$, the powder is considered to have excellent flow, and above $21 \%$, it is considered to have low flow and compression. Since the CI values for ABZ01, ABZ02, and ABZ03 were 35.24, 37.89, and 35.83, respectively, the powder is classified as low flow. The HI is also a measure of flow; values smaller than 1.25 indicate good flow, values higher than 1.5 indicate poor flow, and values between 1.25 and 1.5 indicate that lubricants are required to improve drainage. The HI values for ABZ01, ABZ02, and $A B Z 03$ were $1.57,1.63$, and 1.55 , respectively, thus classifying them as poor-flow powders (Alves et al., 2008).

The angle of repose technique and flow time confirmed the poor flow of ABZ powder, since there was no flow (Alves et al., 2008). Based on all these results from powder rheology, ABZ can be classified as a poor-flow powder, and these findings are of great importance for the pre-formulation study required in drug development (Medeiros, 2010).

Results were evaluated statistically by the Student $t$-test and no statistically significant differences were observed at the $95 \%$ confidence level, between batches ABZ01 and ABZ03. However, some differences were seen in batch ABZ02: the bulk density, compressed density, CI, and $\mathrm{HI}$ values were consistently slightly higher.

\section{$X$-ray diffraction}

Results of XRD analysis for ABZ01, ABZ02, and ABZ03 can be seen in the diffractogram below (Figure 4), with the presence of higher repetitive peaks at $2 \theta$ around $7.3^{\circ}, 11.8^{\circ}, 20.4^{\circ}$, and $24.7^{\circ}$, indicating crystalline behavior of all 3 batches ABZ01, ABZ02, and ABZ03. Consistent with Pranzo et al., (2010), the 3 batches (ABZ01, ABZ02, and ABZ03) were not Form II polymorphs.

However, this result can be used to confirm the absence of polymorphs in the 3 batches only when coupled with findings of differential scanning calorimetry (DSC) techniques in different atmospheres and temperatures and TG/DTG (Storpirtis et al., 2009).

\section{Granulometric and crystal morphology analysis}

Figure 5 displays the results of particle distribution by the sieving method. Powders are described in pharmacopeia as coarse or fine, and the differentiation is made and expressed in terms of the aperture size of the sieve mesh used (Medeiros, 2010; Aulton, 2005). The F. Bras. V

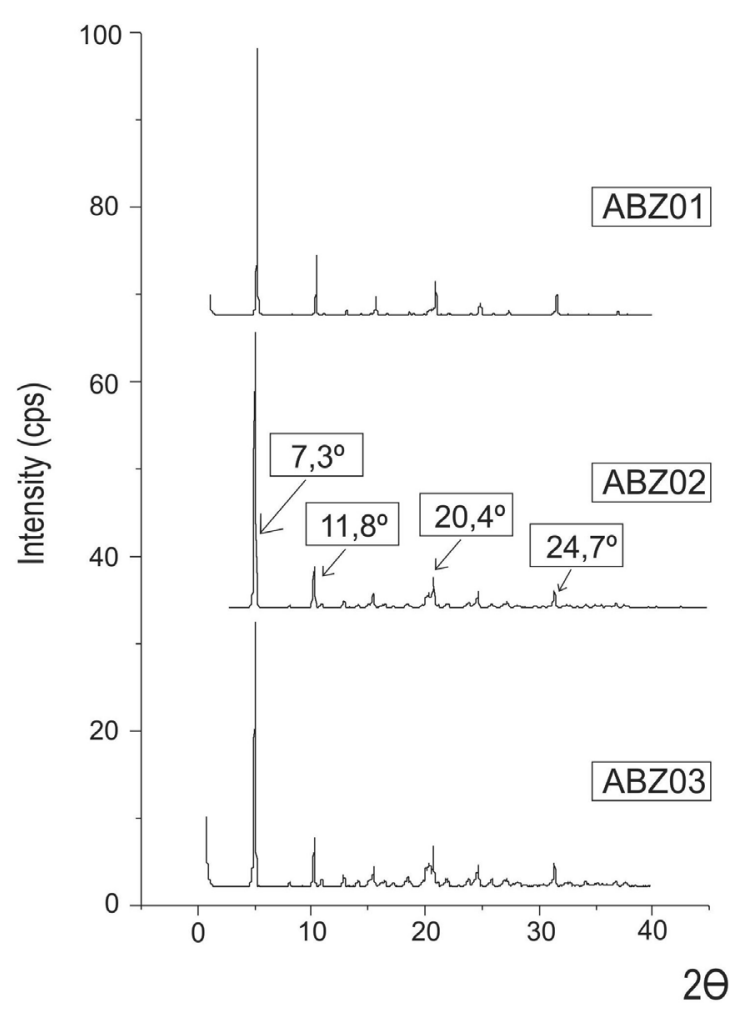

FIGURE 4 - Diffractogram of ABZ01, ABZ02, and ABZ03.

(2010) describes the following classification: coarse particles entirely pass through a sieve with a nominal mesh opening of $1700 \mu \mathrm{m}$; moderately coarse particles pass through a $710-\mu \mathrm{m}$ mesh sieve; moderately fine, fine, and very fine particles pass through $355-\mu \mathrm{m}, 180-\mu \mathrm{m}$, and $125-\mu \mathrm{m}$ mesh sieves, respectively.

The granulometric distribution (Figure 5) showed that $59 \%$ of ABZ01 particles and $62 \%$ of ABZ03 particles were retained in the $250-\mu \mathrm{m}$ sieve, and so they are considered moderately coarse powders, while for ABZ02, 26\% of all particles were retained in the $850-\mu \mathrm{m}$ sieve, $25 \%$

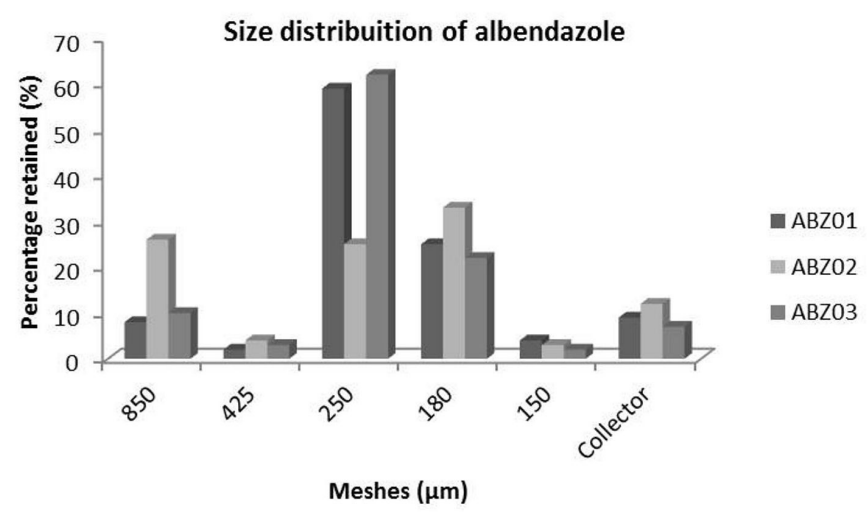

FIGURE 5 - Granulometric distributions of ABZ01, ABZ02, and ABZ03. 
were retained in the $250-\mu \mathrm{m}$ sieve and $33 \%$ in the $180-\mu \mathrm{m}$ sieve, showing a totally non-uniform granulometric distribution that was different from those of batches ABZ01 and ABZ03.

Another method used for particle size evaluation was laser diffraction. A comparative analysis of the average diameters for different percentage populations $(10 \%$, $50 \%$, and $90 \%$ of particles) obtained from the ABZ01, ABZ02, and ABZ03 batches is summarized in Table IV.

Batches ABZ01 and ABZ03 had a very similar particle size distribution, and it was observed that the average particle diameter for batches ABZ01 and ABZ03 were $2.65 \mu \mathrm{m}$ and $2.70 \mu \mathrm{m}$, respectively. However, the batch ABZ02 had a lower average particle size $(1.74 \mu \mathrm{m})$ and is therefore more micronized. According to the DMF of albendazole, $90 \%$ of all particles are smaller than $20 \mu \mathrm{m}$; the results obtained using the laser diffraction technique are in accordance with the DMF, but the results from granulometric distribution by sieving are divergent.
Therefore, there is a need to choose the best technique. Since the DMF is the identity of the API, the chosen technique is probably laser diffraction due to the similar results; however, this is not described in official compendia, and further investigations that may facilitate the quality control of APIs are needed.

With regard to albendazole, strict particle size control is needed, since this physical parameter can change the effectiveness of the pharmaceutical form and has a direct influence on its dissolution rate (Storpirtis et al., 2009).

Crystal morphology analysis by SEM (Figure 6) showed uniformity among the 3 batches, ABZ01, ABZ02 and ABZ03, and a crystalline structure in accordance to the XRD diffractogram, with crystals of different sizes and shapes showing a strong tendency to aggregate (Pranzo et al., 2010).

\section{Thermal characterization}

We verified the thermal profiles of the 3 batches,

TABLE IV - Particle sizes of the 3 batches of ABZ

\begin{tabular}{lcccc}
\hline Batches & $\begin{array}{c}\text { Average diameter } \\
(\mu \mathrm{m})\end{array}$ & $\begin{array}{c}\text { Average diameter 10\% } \\
(\mu \mathrm{m})^{*}\end{array}$ & $\begin{array}{c}\text { Average diameter } 50 \% \\
(\mu \mathrm{m}) *\end{array}$ & $\begin{array}{c}\text { Average diameter } 90 \% \\
(\mu \mathrm{m}) *\end{array}$ \\
\hline $\mathrm{ABZ} 01$ & $2.65 \pm 0.06$ & $1.25 \pm 0.14$ & $3.83 \pm 0.19$ & $12.81 \pm 2.12$ \\
$\mathrm{ABZ} 02$ & $1.74 \pm 0.10$ & $0.98 \pm 0.09$ & $2.15 \pm 0.10$ & $4.97 \pm 0.93$ \\
$\mathrm{ABZ} 03$ & $2.70 \pm 0.11$ & $1.54 \pm 0.15$ & $4.88 \pm 0.68$ & $15.78 \pm 2.59$ \\
\hline
\end{tabular}

*Population of particles (\%) with a diameter lower than the expressed.
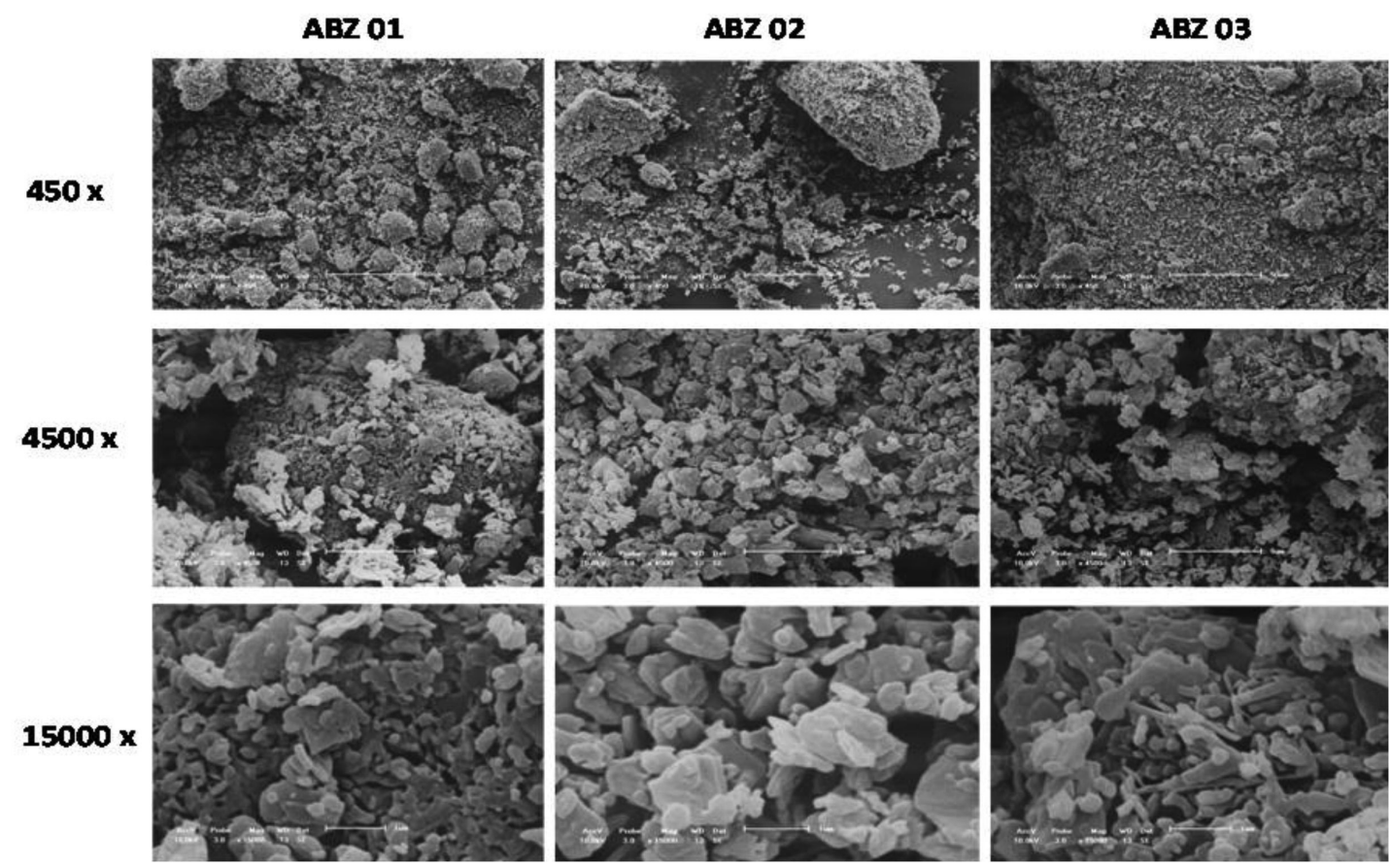

FIGURE 6 - Crystal morphologies of ABZ01, ABZ02, and ABZ03. 
ABZ01, ABZ02, ABZ03, using TG/DTG and DTA curves.

The DTA curve (Figure 7) showed an endothermic melting event. The melting temperatures $\left(T_{\text {peak }}\right)$ and energies for batches $\mathrm{ABZ} 01, \mathrm{ABZ} 02$, and $\mathrm{ABZ} 03$ were $209.27^{\circ} \mathrm{C}$ and $300.26 \mathrm{~J} / \mathrm{g}, 209.89^{\circ} \mathrm{C}$ and $311.97 \mathrm{~J} / \mathrm{g}$, and $209.60{ }^{\circ} \mathrm{C}$ and $314.55 \mathrm{~J} / \mathrm{g}$, respectively, confirming the results of the pharmacopeial method as well as the results obtained with the melting point apparatus.

TG/DTG curves (Figure 8) showed that the first stage of moisture loss occurred at a temperature range of $30{ }^{\circ} \mathrm{C}-105^{\circ} \mathrm{C}$, and a mass loss of $0.78 \%, 1.22 \%$, and $2.08 \%$ for $\mathrm{ABZ} 01, \mathrm{ABZ} 02$, and $\mathrm{ABZ} 03$, respectively; these results do not interfere in the measurements of aqueous and $0.1 \mathrm{M} \mathrm{HCl}$ solubility.
We also verified 4 other decomposition stages for the batches ABZ01, ABZ02, and ABZ03. The first stage began between $197.22{ }^{\circ} \mathrm{C}$ and $205.94{ }^{\circ} \mathrm{C}$ with a mass loss of $3.70 \%$ to $4.13 \%$; the second stage began between $219.22{ }^{\circ} \mathrm{C}$ and $243.03{ }^{\circ} \mathrm{C}$, with a mass loss of $9.33 \%$ to $10.85 \%$; the third stage began between $319.50{ }^{\circ} \mathrm{C}$ and $349.00{ }^{\circ} \mathrm{C}$ with a mass loss of $15.41 \%$ to $16.25 \%$; and the last stage began between $372.21^{\circ} \mathrm{C}$ and $399.59^{\circ} \mathrm{C}$, with a mass loss of $25.45 \%$ to $28.43 \%$.

\section{CONCLUSION}

The present study was of great importance to gather crucial information on the physical and physicochemical

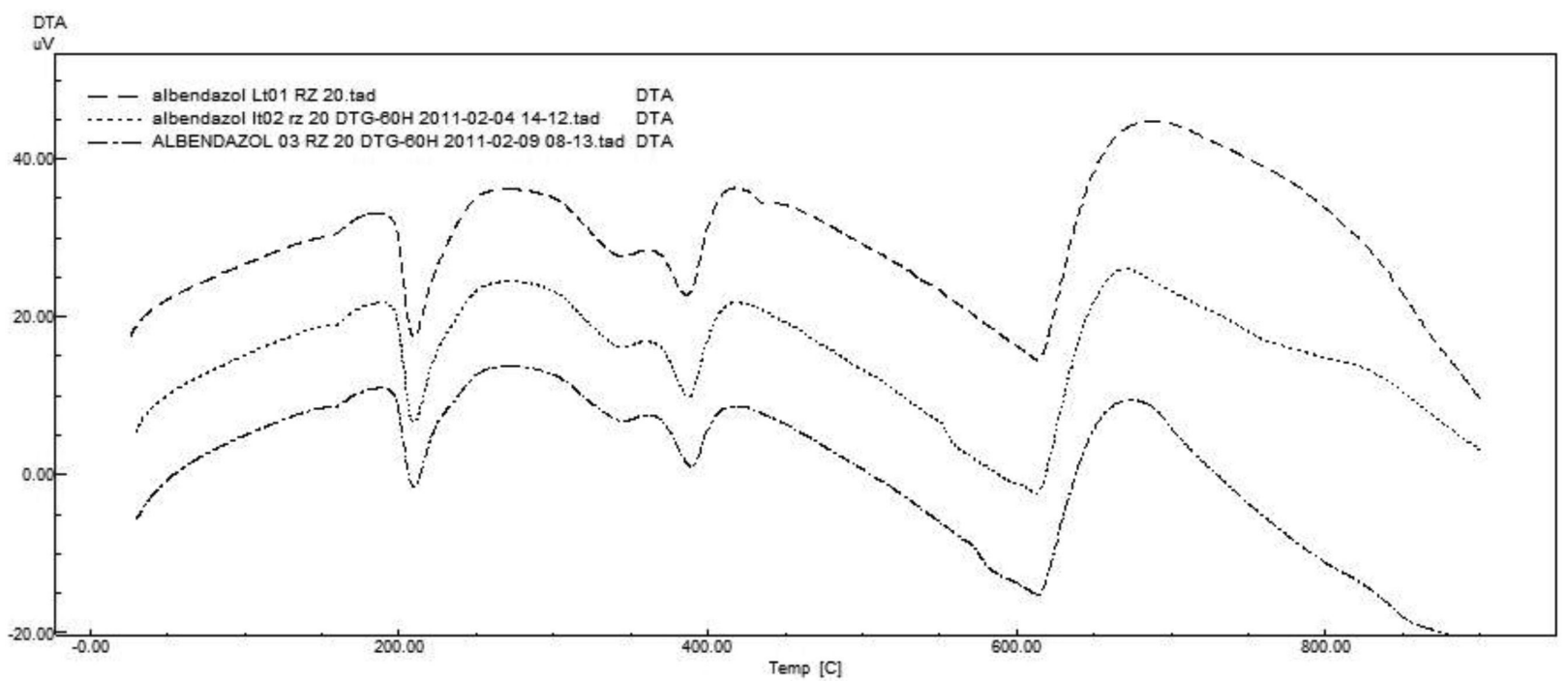

FIGURE 7 - Thermal profile of the 3 batches ABZ01, ABZ02, ABZ03 based on DTA curves.

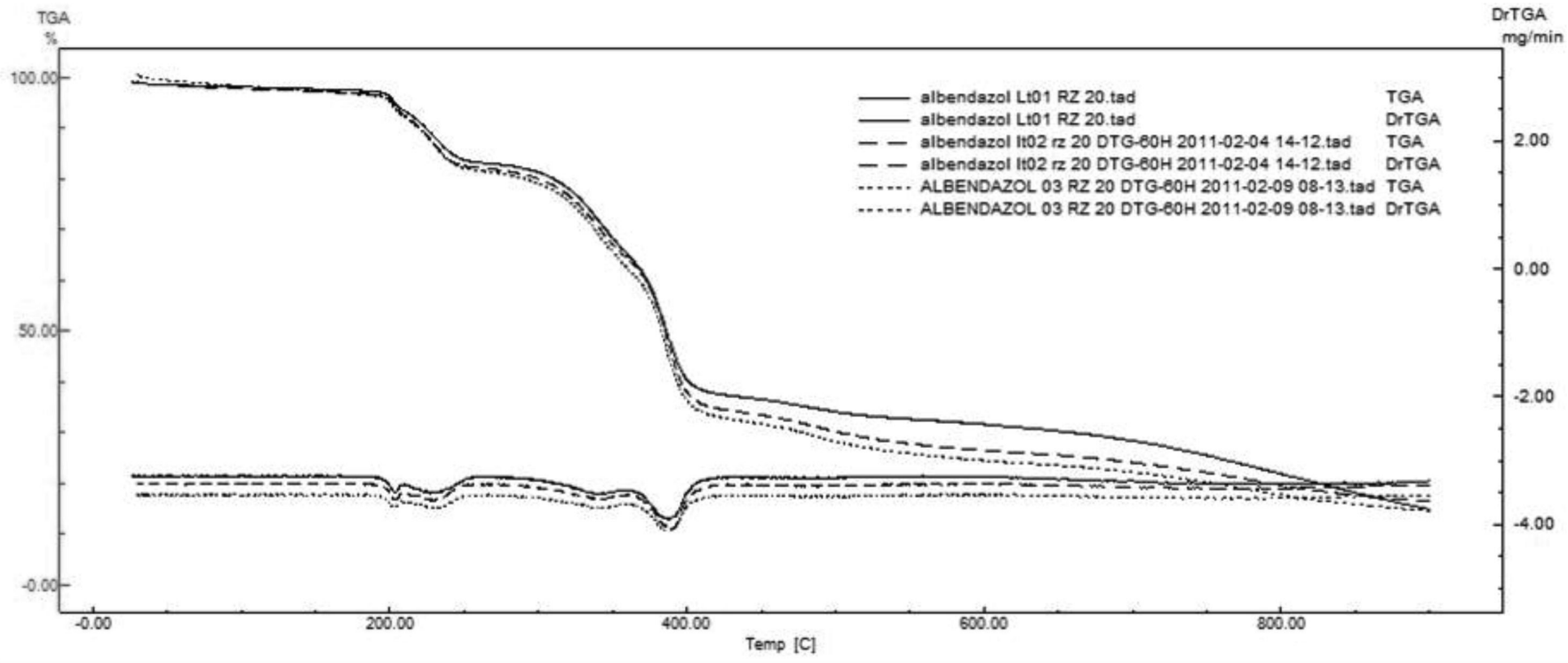

FIGURE 8 - Thermal profile of the 3 batches, ABZ01, ABZ02, and ABZ03, based on TG/DTG curves. 
characteristics of ABZ, with the aim of facilitating better pharmacotechnical monitoring of the drug and improving routine quality control in the pharmaceutical industry.

It is observed that pharmacopeial techniques alone are not sufficient to identify differences in batches. Complementary techniques are more sensitive and discriminating, making it possible to obtain more precise information on the API, thereby ensuring batch-to-batch standardization.

Therefore, it is necessary to include scientific foundations for the development of quality control assays for the tested API, ABZ, to provide insights into its physicochemical properties, which can be used as a reference for other studies. This will allow the acquisition of knowledge that can be systematically used in the investigation and characterization of other therapeutic classes of APIs.

Thus, for quality evaluation of ABZ and other APIs, it is also necessary to evaluate many quality control techniques in order to establish limits with well-defined specifications for parameters such as identification (infrared spectroscopy, NMR, and dosing) and other characterization techniques (particle size, density, and thermal analysis).

\section{ACKNOWLEDGMENTS}

We acknowledge Fundação de Amparo à Ciência e Tecnologia do Estado de Pernambuco (FACEPE) and Núcleo de Desenvolvimento Farmacêutico e Cosmético (NUDFAC - UFPE) for financial support, and the Central Analítica do Departamento de Química Fundamental (DQF - UFPE) and to Laboratório de Tecnologia de Medicamentos (LTM) for the performed analyses.

\section{REFERENCES}

ALANAZI, F.K.; EL-BADRY, M.; AHMED, M.O.; ALSARRA, A.I. Improvement of albendazole dissolution by preparing microparticles using spray-drying technique. Sci. Pharm., v.75, n.2, p.63-79, 2007.

ALENCAR, J.S.; BEDOR, D.C.G.; MEDEIROS, F.; ALENCAR, J.R.B.; LEITE, A.C.L; BRONDANI, D.J.; GALEMBECK, A.; MACEDO, R.; ALBUQUERQUE, M.M.; ROLIM NETO, P.J. Caracterização e propriedades térmicas do Ritonavir para qualificacão de fornecedores. Acta Farm. Bonaerense, v.25, n.2, p.170-1766, 2006.
ALVES, G.M.C.; ROLIM, L.A.; ROLIM NETO, P.J.; LEITE, A.C.; BRONDANI, D.J.; MEDEIROS, F.P.M.; BIEBER, L.W.; MENDONÇA JÚNIOR, F.J.B. Purificação e caracterização da $\beta$-Lapachona e estudo de estabilidade dos cristais em diferentes condições de armazenamento. Quím. Nova, v.31, n.2, p.413-416, 2008.

AULTON, M.E. Delineamento de formas farmacêuticas. 2.ed. Porto Alegre: Artmed, 2005. 678 p.

AGÊNCIA NACIONAL DE VIGILÂNCIA SANITÁRIA. ANVISA. Lista de medicamentos de referência e lista de medicamentos genéricos. Available at: $<\mathrm{http}: / / \mathrm{www}$.anvisa. gov.br/medicamentos/referencia/solicita.htm>. Accessed on: 13 Dec. 2010.

AGÊNCIA NACIONAL DE VIGILÂNCIA SANITÁRIA. ANVISA. Resolução RE nº 899, de 29 de Maio de 2003. Diário Oficial da República Federativa do Brasil, Brasília, 02 Jun. 2003. Seção1, p.17.

CARINI, J.P.; PAVEI, C.; SILVA, A.P.C; MACHADO, G.; MEXIAS, A.S.; PEREIRA, V.P.; FIALHO, S.L.; MAYORGA, P. Investigação preliminar avaliando a influência dos processos de compactação e trituração em relação às propriedades cristalinas e polimórficas da Talidomida. Lat. Am. J. Pharm., v.28, n.2, p.226-233, 2009.

FARMACOPÉIA BRASILEIRA. Parte II. 5.ed. São Paulo: Atheneu, 2010. p.40.

LINDENBERG, M.; KOPP, S.; DRESSMAN, J.B. Classification of orally administered drugs on the World Health Organization Model list of Essential Medicines according to the biopharmaceutics classification system. Eur. J. Pharm. Biopharm., v.58, n.3, p.265-278, 2004.

LOPES, P.Q. Estudos de correlação da estabilidade térmica e dissolução intrínseca do albendazol e os parâmetros farmacotécnicos das suas formulações. Recife, 2007.59 p. [Dissertation of Master degree. Faculty of Pharmaceutical Sciences, Federal University of Pernambuco].

MAXIMIANO, F.P.;CISTA, G.H.Y.; SOUZA, J.; CUNHAFILHO, M.S.S. Caracterização físico-química do fármaco antichagásico Benznidazol. Quím. Nova, v.33, n.8, p.1714$1719,2010$. 
MEDEIROS, F.P.M. Potenciais formulações com o benznidazol para tratamento de crianças com a doença de Chagas. Recife, 2010. 173 p. [Tese de Doutorado. Department of Pharmaceutical Sciences, Federal University of Pernambuco].

MERCK INDEX. 12.ed. Whitehouse Station: Merck Research Laboratories, Division of Merck \& Co., 1996. p.39.

MORIWAKI. C.; COSTA, G.L.; FERRACINI, C.N.; MORAES, F.F.; ZANIN, G.M.; PINEDA, E.A.G.; MATIOLI, G. Enhancement of solubility of Albendazole by complexation with $\beta$-cyclodextrin. Braz. J. Chem. Eng., v.25, n.2, p.255$267,2008$.

NERY, C.G.C.; PIRES, M.A.S.; PIANETTI, G.A.; SOARES, C.D.V. Caracterização do fármaco hipoglicemiante Glibenclamida. Braz. J. Pharm. Sci., v.44, n.1, p.61-73, 2008.
PRANZO, M.B.; CRUICKSHANK, D.; CORUZZI, M.; CAIRA, M.R.; BETTINI, R. Enantiotropically related albendazole polymorphs. J. Pharm. Sci., v.99, n.9, p.3731$3742,2010$.

SOARES SOBRINHO, J.L.; LYRA, M.A.M.; ALVES, L.D.S.; ROLIM NETO, P.J. Caracterização Físico-Química do Tripanomicida Benznidazol para o Desenvolvimento de Medicamentos. Lat. Am. J. Pharm., v.29, n.5, p.803-807, 2010.

STORPIRTIS S.; GONÇALVES, J.E.; CHIANN, C. Ciências Farmacêuticas: Biofarmacotécnica. Rio de Janeiro: Guanabara Koogan, 2009.

United States Pharmacopoeia. 30.ed. Rockville: United States Pharmacopoeial Convention, 2007. p.242.

Received for publication on $24^{\text {th }}$ August 2011 Accepted for publication on $05^{\text {th }}$ April 2012 